\title{
Inhabiting Whiteness: The Eoan Group La traviata, 1956
}

\section{JULIANA M. PISTORIUS*}

\begin{abstract}
Active at the height of the apartheid regime, the Eoan Group treated South Africans to operas 'in the true tradition of Italy'. The group relied on elaborate, naturalistic stage settings and the most stereotypical of operatic conventions to construct a hereditary link between itself and Italy, thus creating an alignment with the cultural ideal of Europe and its colonial representative -whiteness. This article offers a materialist reading of the Eoan Group's first operatic endeavour, La traviata in 1956, to argue that their invocation and emulation of the 'Italian tradition' served to situate them within a class-based discourse of racially inscribed civility. Drawing on archival records relating to props, costumes, advertisements and funding, it shows how the group constructed an imagined Italian heritage both to emphasise the quality of their productions, and to create an affinity with their white audiences. In this reading, the construction of an Italian operatic tradition functions not as a neutral aesthetic category, but as a historically situated politics of race and class.
\end{abstract}

On Saturday 10 March 1956, a sold-out City Hall audience in Cape Town witnessed 'a miracle'. These were the words of Italian tenor Alessandro Rota, describing 'an excellent performance of Verdi's immortal opera La traviata'. It was opening night, and Rota, the event's producer, was predictably enthusiastic about the result. What prompted his 'historical statement' on that 'most memorable occasion', however, was neither the identity of the work in question nor the quality of its performance. Rather, Rota's miracle referred to the night's performers: the Eoan Group, a local welfare organisation committed to the promotion of amateur artistic activities and consisting entirely of members of the so-called 'coloured' race. ${ }^{2}$

\footnotetext{
* Juliana M. Pistorius, University of Huddersfield; j.pistorius@hud.ac.uk 1 '1965 Opera Season Advance Press Publicity', 15 February 1965, Eoan Group Archive 2:10.

${ }^{2}$ In post-apartheid South Africa, the use of racial terminology codified and endorsed by the regime is a controversial matter, and one that has no easy solution. The continued use of apartheid-era language serves to sustain semantically a system that has been discredited in every other way. Simultaneously, however, it remains impossible to write about this system without invoking the categories on which it
} 
It was a night of firsts. The first time, arguably, that La traviata had been performed in Cape Town; ${ }^{3}$ the first time an opera had been performed in South Africa by a non-white cast; and the first night of the Eoan Group's operatic career - one that would eventually span twenty years, eleven seasons and ten operas. ${ }^{4}$ It was also the first venture in a project of self-stylisation that transformed the group's members from amateurs 'who [had] never seen Italian Opera, [had] limited or no knowledge of music, [had] not had vocal training and [could] not speak the Italian language, ${ }^{5}$ into the heirs to an idealised Italian operatic tradition. Advertising their Traviata as 'the first time in the history of music that the complete Italian opera will be traditionally produced and sung in the Italian language by an entirely Non-European cast and company', the group proclaimed an artistic agenda that was to have a profound impact on the product they presented on stage ${ }^{6}$ With directorial and scenographic decisions inspired by 'the traditional Italian style', this first operatic endeavour was an exaggeratedly naturalistic vision of material splendour, directly informed by what was to become the Eoan Group's signature claim, that they presented their operas 'in the true Italian operatic tradition'.7.

This article examines the material aspects of Eoan's 1956 Traviata to begin to reconstruct the visual and sonic characteristics of the group's artistic agenda. Props lists, costumes and set constructions, read in dialogue with the group's publicity and calls for funding, reveal an

relied for its implementation and preservation. For the sake of clarity, I shall use the racial classifications inherited from apartheid discourse. My discomfort with these terms, however, will be indicated firstly by non-capitalisation, and secondly by presenting the initial occurrence of each term between inverted commas.

${ }^{3}$ In the absence of conclusive evidence, Hilde Roos makes a convincing case, in 'Remembering to Forget the Eoan Group - The Legacy of an Opera Company from the Apartheid Era', South African Theatre Journal 27 (2014), 1-18, that this was the first complete Italian performance of La traviata in Cape Town. ${ }^{4}$ For a chronological account of the Eoan Group's history, see Hilde Roos, 'Opera Production in the Western Cape: Strategies in Search of Indigenization’ (PhD dissertation, Stellenbosch University, 2010). 5 ‘1965 Opera Season Advance Press Publicity’.

${ }^{6}$ Correspondence, Joseph Manca to Miss Hasker of G. Ricordi, 18 November 1955 (Eoan Group Archive 29:200).

7 ‘1965 Opera Season Advance Press Publicity’, 15 February 1965 (Eoan Group Archive 2:10); original emphasis.

8 'The Eoan Group Arts Festival: Introductory Remarks by Joseph Manca’, 1956 (Eoan Group Archive $1: 4)$. 
Italianate ideal realised in terms of material excess. ${ }^{9}$ Proceeding from a detailed consideration of these documents, I argue that the physical dimensions of the group's productions summoned a class-based racial discourse strongly aligned with the politics of coloured aspiration, and that these productions sought to transcend colouredness by evoking sophisticated, white worlds for the Eoan singers and their audiences to inhabit. While Hilde Roos has considered Eoan's rhetoric of authenticity and tradition from the perspective of indigenisation, ${ }^{10}$ my article situates the group's aesthetic agenda within an aspirational discourse linking coloured artistry to European, and by extension white, cultural accomplishment. If Roos's analysis seeks to show how the Eoan Group brought Italian opera 'into' South Africa, thus making it a local form, this article aims to do the opposite: rather than reading the Eoan operas as instances of indigenisation — of bringing something in-I want to understand these productions as reaching out, as attempts to transcend the physical (and racial) boundaries of the here and now, and to stretch towards a European ideal.

In what follows, I provide a materialist reading of the Eoan Group's operatic endeavours, thereby linking their staging practices to an aspirationalism grounded not in experiences of collectivity, but rather in the acceptance and normalisation of racial and class divisions. Interrogating the racial implications of naturalistic staging and the 'Italian tradition' in

\footnotetext{
9 All primary sources cited in this article reside in the Eoan Group Archive, hosted at the Documentation Centre for Music (DOMUS), Stellenbosch University, South Africa. The Eoan Group's complete archive was discovered beneath the stage of the Joseph Stone Theatre in Athlone, Cape Town, in 2010. For more on the discovery of the archive and its subsequent transfer to DOMUS, see Hilde Roos, 'Remembering to Forget', 5-6.

${ }^{10}$ Roos, 'Indigenisation and History: How Opera in South Africa Became South African Opera'. Acta Academica Supplementum 2012 (2012), 117-55. Hilde Roos conducted the first exhaustive survey of the material in the Eoan Group Archive, which remains uncatalogued. She was also a steering member of the Eoan History Project, which conducted a series of interviews with former members, extracts from which have been published as Eoan: Our Story (eds. Hilde Roos and Wayne Muller, Johannesburg, 2013), and as a film entitled An Inconsolable Memory (dir. Aryan Kaganof, Johannesburg, 2013). Roos's own publications have done much to reconstruct the history of the group ('Remembering to Forget', 2014), to situate them within the broader history of South African opera production, and to investigate the role their activities played in the subsequent adoption of opera as an indigenous South African art form ('Indigenisation and History', 2012). I am grateful for the generosity with which she has shared her own knowledge of the archive. In the current text, I have not been able to take account of Roos's monograph, The La Traviata Affair: Opera in the Age of Apartheid (Berkeley, 2018), which was published after this article went to press; instead, I engage with Roos's previously published work.
} 
1956 South Africa, I situate discourses of operatic convention within the politically fraught context of disenfranchised coloured life under apartheid. In this reading, the Italian tradition as idealised construct provided the physical tools with which to simulate an escape from coloured reality by contriving a cultural heritage paradoxically free from and overdetermined by race.

\section{Staging La traviata, 1956}

The Eoan group inaugurated its opera career under the musical directorship of Joseph Salvatore Manca, a South African-born accountant of Italian parentage, who had become the group's choir conductor in 1943. Manca, an amateur composer and conductor, cherished grand operatic ambitions, and considered it his God-given duty to channel these towards the 'enlightenment, education, and enjoyment' of the coloured people. ${ }^{11}$ This divine calling - which Manca referred to as his 'mission in music' - reached its first milestone when La traviata opened in 1956, with a cast consisting entirely of Eoan members. Sopranos May Abrahamse and Ruth Goodwin alternated in the role of Violetta, tenor Ron Thebus sang Alfredo; Germont was sung by baritone Lionel Fourie, Annina by Linda Rinquest and bass Robert Trussell made his debut as the Doctor. The chorus was drawn from the Eoan Group Adult Choir, and the second-act ballet was performed by members of the Eoan Group Ballet. ${ }^{12}$ Only the orchestra did not incorporate members of the Eoan Group: continuing a relationship already established during the group's numerous oratorio and operetta performances between 1949 and 1954, the whites-only Cape Town Municipal Orchestra provided the accompaniment. ${ }^{13}$

This first operatic endeavour by the group began to foster a reputation for spectacle and glamour: enormous effort went into creating a visually arresting display and members were encouraged to give to the production what they could. A list of stage properties shows that many

\footnotetext{
${ }^{11}$ Correspondence, Joseph Manca to Andrew Mackrill, 12 July 1955 (Eoan Group Archive 29:201).

12 'The Eoan Group Arts Festival: Introductory Remarks by Joseph Manca'.

${ }^{13}$ See 'History of the Eoan Group' in 'Programme, 1956 Arts Festival' (Eoan Group Archive 29:200). The Cape Town Municipal Orchestra later became known as the Cape Town Symphony Orchestra; it is currently called Cape Town Philharmonic Orchestra.
} 
of the furnishings were sourced from within the group. Secretary Mrs Alethea Jansen lent a sofa and $\mathrm{Mr}$ Adams contributed an old-fashioned clock. Mrs Cooke supplied four champagne buckets, twelve sheets of note paper, a pen and ink stand, an armchair, a bed stool, a dressing table with mirror, a mantelpiece mirror, a bottle of water and various medicine bottles. The group as a whole was tasked with obtaining ten empty champagne bottles, six dozen artificial flowers and a bed. ${ }^{14}$ Costumes, likewise, came from within the ranks of the group, although they were not borrowed but handmade by a group of volunteers known as the 'Eoan Group Sewing Women'. ${ }^{15}$ Photographs and costume lists for the 1956 Traviata attest to evening gowns in rich fabrics, gloves, fans, cloaks, evening suits, military uniforms, full livery, canes and hats. ${ }^{16}$ Men and women, principals and chorus, were all dressed in splendid finery. Figure 1, a photograph of Act 2 Scene 2 from the 1956 production, provides a sense of the grandeur. The ailing Violetta (May Abrahamse) is seated, with a concerned Dr Grenvil (Robert Trussell) and Flora (Edna Herman) attending to her; Arthur Ackerman's Baron Douphol hovers in the background. Each is clothed in elaborate period costume - the women in shining dresses with wide skirts and extravagant necklines, the men in military uniform or evening attire complete with ornate cravats. The result of the group's collective effort was unprecedented splendour in the eyes of the audience. Die Burger's music critic, Emol (identified by Roos as well-known Afrikaans critic Charlie Weich), ${ }^{17}$ accorded the visual dimension a unique place in the history of Cape Town opera productions, claiming that the costumes were 'of the most beautiful and glamorous [he] had ever seen'. ${ }^{18}$

14 'Eoan Group Arts Festival: Stage Properties, La Traviata' (Eoan Group Archive 29:200).

15 'Programme, 1956 Arts Festival' (Eoan Group Archive 29:200).

16 'La Traviata Costumes, Principals' (Eoan Group Archive 82:632); 'La Traviata Costumes, Chorus' (Eoan Group Archive 82:632).

17 Roos, 'Opera Production', 83.

18 Die kostuums was van die mooiste en deftigste wat ek al ooit gesien het. 'Kaapse Kleurlinge Voer Italiaanse Opera met Groot Welslae Uit' [Cape Coloureds Perform Italian Opera With Great Success], Die Burger, 12 March 1956 (Eoan Group Archive, Ruth Fourie Newspaper Cuttings). 


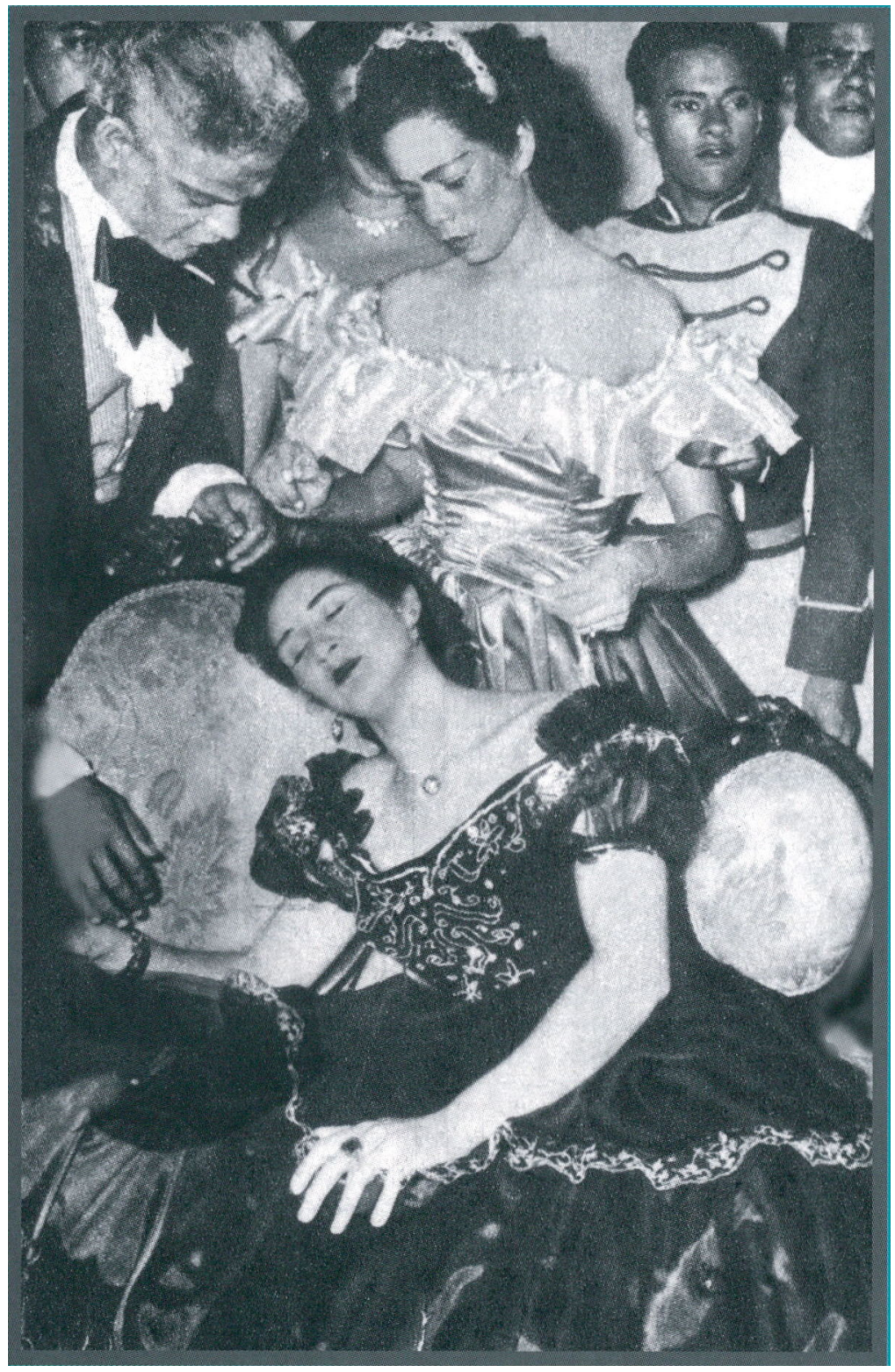

Fig. 1: Act II, Scene 2 from La traviata, 1956, reproduced in Programme, La traviata, 22 April - 2 May 2004, 61 (no folder). Reproduced with Permission.

The group's stage designs were as elaborate as their costumes. The props list for Act 1, for instance, reveals a preoccupation with the minutiae of staging that borders on caricature. Some of these items will be familiar from their association with specific group members; others, like the four dozen full dining sets, were rented from a commercial supplier: ${ }^{19}$

19 'Eoan Group Arts Festival: Stage Properties, La Traviata'. 
$\underline{\text { Act I }}$

2 Long Trestle Tables

5 Small Tables

1 Sofa

7 Chairs (Golden) for Principals

30 Chairs for Chorus (Ornate)

2 Large Table Cloths for Trestle Tables

5 Table Cloths for Round Tables

4 Dozen Serviettes

4 Dozen Knives

4 Dozen Forks

4 Dozen Plates

4 Champagne Buckets

1 Full Bottle Champagne for each performance

10 Empty Champagne Bottles

4 Dozen Champagne Glasses

7 Table Chandeliers with 3 Candles in each

1 Larger Table Chandelier

1 Large Crystal Chandelier Hanging from the Ceiling

1 Large Mirror

6 Fruit Holders

12 Serving Trays

6 Dozen Artificial Flowers

Strings of Garlanded Flowers for attaching to the Table Cloths

1 Large Basket for Flowers at Centre Back Stage 
The naturalistic attention to detail revealed in this props list diverges from practices more widely associated with the 1950s: it resembles neither the defamiliarisation of Regietheater that pervaded professional stages across Europe at the time, ${ }^{20}$ nor does it suggest the austerity identified by John Lowerson in post-war amateur opera in Britain. ${ }^{21}$ If anything, the detail and extravagance of the Eoan stage lends itself to comparison with provincial Italian opera houses, which, according to Philip Gossett, continue to betray a preference for conventional, naturalistic stagings of standard Italian operatic repertoire. ${ }^{22}$ The Eoan Group did indeed seek to trace a link between their productions and those in Italy. Their ambitions, however, reached beyond the limits of provincial houses: they believed that their operas evoked no less a stage than the Teatro alla Scala itself. The advance publicity for its 1962 opera season, for instance, declared 'Ambition: The Eoan Group not only intends to maintain its already high standard of opera presentation, but to raise it to further heights, and in this season it is doing its best to give Cape Town opera as it is done at "La Scala", Italy. ${ }^{23}$ Even in private correspondence, Manca emphasised the importance of La Scala as a model for the Eoan Group stage. In 1961 he updated Eoan’s champion in Johannesburg, Ian Bernhardt, on preparations for the 1962 season, with a guarantee that the group's planned productions of La traviata, La bohème, and Madama Butterfly would compare favourably with those of its paragon: 'I can assure you that we are saving no expense in presenting these three Operas on the same scale as is done at La Scala in Italy,. ${ }^{24}$

Eoan's emulation of the most famous theatre in Italy was already evident in their first production of La traviata. A set of picture postcards in the Eoan Group Archive explicitly connects the set designs of this production with those of a Traviata mounted by La Scala: in Folder 29:200, which contains various documents pertaining to the 1956 Traviata, four 'Photographs of La Traviata at La Scala' are mounted on a double A4 folio. Each picture gives a

${ }^{20}$ Carolyn Abbate and Roger Parker, A History of Opera: The Last 400 Years (London, 2015), 524-5.

${ }^{21}$ John Lowerson, Amateur Operatics: A Social and Cultural History (Manchester, 2005), 123.

22 Philip Gossett, Divas and Scholars: Performing Italian Opera (Chicago, 2006), 452.

23 ‘Advance Publicity, 1962 Opera Season' (Eoan Group Archive 82:632).

${ }^{24}$ Correspondence, Manca to Ian Bernhardt, 24 May 196 (Eoan Group Archive 33:226). 
complete view of the stage for a different scene from the opera, and together they present the complete scenery and staging for one of the theatre's productions. Dated the year XXI of the Italian Fascist era (29 October 1942 to 25 July 1943), the photographs depict a series of performances that took place on 11,17,26, and 30 April 1943. The production was conducted by Gino Marinuzzi and Nino Sanzogno, directed by Giuseppe Marchioro, and designed by Giovanni Grandi, with Nicola Benois as stage manager. ${ }^{25}$

The extent to which these pictures from La Scala served as direct inspiration for the Eoan Group's stage design becomes evident when Act 2 Scene 2 is compared across the two productions. A photograph by renowned South African photographer Cloete Breytenbach, reproduced in Eoan: Our Story (Figure 3), ${ }^{26}$ shows a set construction for Eoan's 1956 Traviata that is almost identical to the La Scala photograph of the same scene (Figure 2). In both, the back wall of the stage is turned into a grand entrance consisting of three elaborately decorated arches arranged at a slight angle. The elevation of the singers in the Milanese picture suggests a set of three steps similar to those in the Eoan photograph, and both productions are lit by ornate chandeliers. Despite the fact that the Cape Town City Hall stage was significantly smaller than that of La Scala, the scenographer managed to place a table and a chandelier in almost exactly the same location (stage left).

Eoan's Traviata sets were designed and constructed by Joseph Cappon, an Italian artist and scenographer who had settled in South Africa in the early 1930s. Born in Trieste in 1891, he had studied at the Accademia di Belle Arti di Brera in Milan before becoming a professional scenographer. ${ }^{27}$ Cappon brought both a formidable reputation and a Milanese background, and his considerable experience was surely invaluable in realising the group's emulative ideals. His

25 'Photographs of La Traviata at La Scala' (Eoan Group Archive 29:200). My thanks to Matteo Sartorio of the Archivio del Museo Teatrale alla Scala e Biblioteca Livia Simoni for his assistance in tracking down further details about this production.

${ }^{26}$ Eoan History Project, Eoan: Our Story (Johannesburg, 2013), 128-9. My thanks to Mr Breytenbach for his kind permission to reproduce this image.

27 'The Wayfarer's Talk of the Day: Watching from the Wings: An Opera in Rehearsal', Daily News, 28 July 1960 (Eoan Group Archive 30:208). 


\section{NII ACT: Scene 2.}

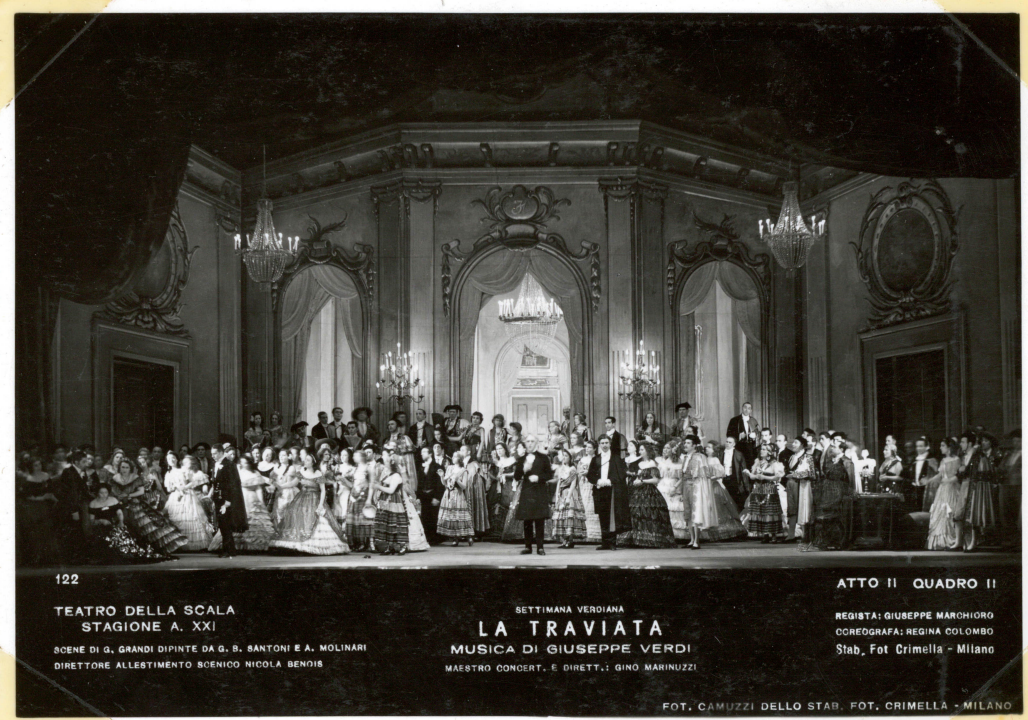

Fig. 2: 'Photographs of La Traviata at La Scala', Act II, Scene 2, 29:200. Reproduced with Permission.

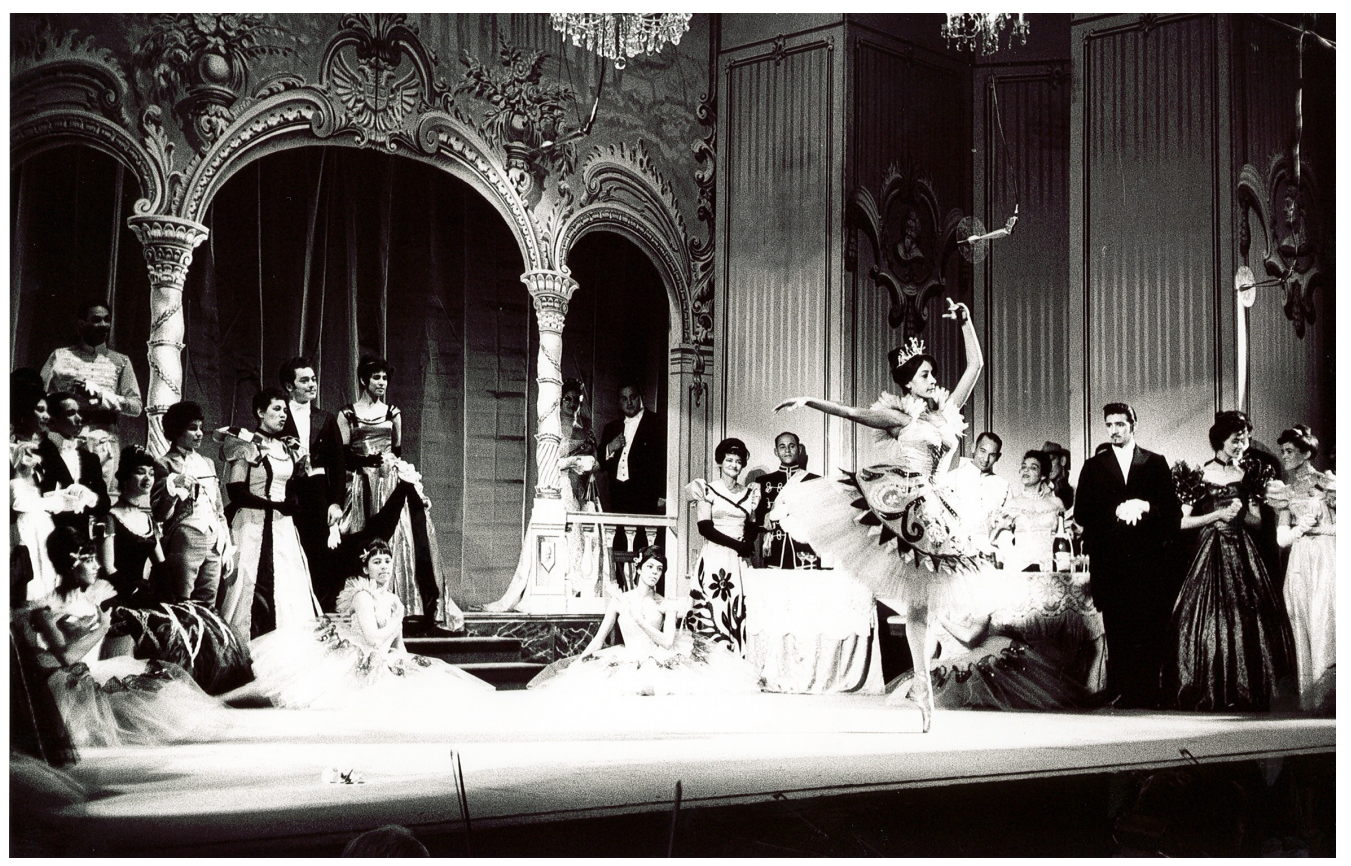

Fig. 3: La traviata, 1965, photograph by Cloete Breytenbach in Eoan: Our Story, 128-9.

Reproduced with Permission. 
Italian heritage, together with that of Rota and (at a generational remove) Manca, added a veneer of authenticity to the group's claim that they presented their operas in the Italian tradition.

\section{Constructing a past: the 'Italian tradition'}

The idea of 'tradition' was a trope throughout Eoan's performance career. In publicity material for their opera seasons, great care was taken to emphasise fidelity to an Italian operatic heritage. Manca's essay 'Introduction to Opera', published in Eoan programmes during the 1950s and 60s, emphasised that the group's members were 'singing and acting in the true tradition of Italy, the country of the birth of Opera where it has become part of the natural life of the peoplee. ${ }^{28}$ Calls for private and government financial support also stressed the group's claims to an Italian tradition, notably when they put out a call for public subscription with the claim that it was the music section that first aroused world-wide interest in the activities of Eoan, by its presentation of Italian Opera, sung in the original language and performed in the traditional Italian manner'. ${ }^{29}$ Likewise, publicity material for opera seasons underlined the authenticity of production designs. Advance publicity for the 1962 season, for instance, stated that 'special period furniture has been designed and made, adding authenticity to the production [of La traviata]', while the costumes for Madama Butterfly during the same season were described as follows: 'Special new costumes have been designed and made, no expense has been spared in their creation, which is as authentic as is possible to make'. ${ }^{30}$ The repeated references to authenticity, veracity and tradition in these documents and others sought to persuade by their very persistence. Yet they contain little information on what exactly the Eoan Group meant by a true Italian operatic tradition. The publicity material for their first Traviata nevertheless provides some insight:

\footnotetext{
28 'Introduction to Opera by Joseph Manca' (Eoan Group Archive 28:194).

29 'Eoan Group Call for Financial Support by Subscription' (Eoan Group Archive 20:140).

30 'Advance Publicity, 1962 Opera Season'.
} 
This will be a full-scale production with all the tradition, costumes, scenery, ballet etc. demanded in the recognised presentation of Italian Opera. The number of performers taking part is over 80 strong, including Principals, Chorus and Ballet Dancers. ${ }^{31}$

What 'tradition' signifies is left to the reader's imagination, but as costumes, décor and dancing are specified separately, it is possible that the word refers to the pomp popularly associated with opera-as-event: the lush surroundings of the theatre; the often unspoken codes guiding audience behaviour; and, of course, the live orchestra. This definition diverges significantly from that proposed by Gossett, who acknowledges that “"tradition” [is] a concept whose meaning remains elusive', but goes on to specify 'traditions of musical performance' as 'places in an opera where conductors or singers at some moment between the composition of the work and the present have altered or modified the printed musical text, for whatever reason, and where the changes introduced have been accepted by other performers, sometimes being passed on from one generation to the next'. ${ }^{32}$ Nowhere in the Eoan Group's references to 'tradition' are there allusions to scores, texts, conductors or even composers. The idea of authorial intention, or of a turn to historically informed performance, cannot then apply to their particular brand of 'tradition'. Elsewhere, however, Gossett ruminates on a notion of 'Italian operatic tradition' more closely resembling that of the Eoan group when he observes that 'safe and predictable' productions were perceived until well into the twentieth century to be part of a continuous tradition of Italian opera:

Despite occasional incursions and provocations ... most performances of the basic Italian repertory - particularly in Italy itself - were safe and predictable. They told the

31 'The Eoan Group Arts Festival: Introductory Remarks by Joseph Manca', 1956 (Eoan Group Archive $1: 4)$.

32 Philip Gossett, 'Critical Editions and Performances', in Alison Latham and Roger Parker, eds., Verdi in Performance (Oxford, 2001), 133-44, at 134, 140. 
story (sometimes well, sometimes poorly), and they presented it in recognizable, basically naturalistic settings. Just as musicians lived under the illusion that the scores from which they were performing had roots in a continuous tradition that transmitted accurate and authentic texts, so too did audiences believe that the essential conventions of staging and set design had been passed down from generation to generation. ${ }^{33}$

This sense of 'pastness', of being heirs to what had become before, invokes Gabriele Dotto's understanding of operatic transmission, in which 'tradition' suggests the assumption of a direct heredity from the original to the (re)production. ${ }^{34}$ The Eoan group's productions exactly matched Gossett's description: they were safe, predictable, conventional and naturalistic. In the directorial hands of a trio of Italians, they traced a lineage from Italy to Eoan. The group's promotion of an 'Italian operatic tradition' was hence both functional and affective: it created a European affiliation for its members.

For Hilde Roos, the rhetoric of truth and authenticity espoused by the group served to integrate Italian opera within the South African musical and social sphere. Translating the 'Italian operatic tradition' from an abstract concept to a tangible endeavour marked by compassion and affirmation, Eoan's Italian operas, she argues, were localised without a need for recourse to adaptation or adjustment:

The group's insistence on producing opera in 'true Italian fashion' presents a conundrum with regards to the idea of indigenisation. Apart from the racist expectation that Coloured people would perform opera differently, the group's acceptance of Italian opera as a site of music-making, self-confirmation and shared humanity made of Italian

33 Gossett, Divas and Scholars, 452.

34 Gabriele Dotto, 'On “Traditional” Performance', in Latham and Parker, Verdi in Performance, 151-6. 
opera a South African genre, without it needing to mutate or change into something 'South African'. 35

It is unclear how the notions of 'music-making, self-confirmation and shared humanity' identified in this reading of Italian opera rendered the genre 'South African'. If anything, Roos seems to characterise these qualities as universal features of the operatic genre - capable of transcending race, and therefore showing up assumptions that 'Coloured people would perform opera differently'. Given that Roos approaches the Eoan Group's productions specifically from the perspective of indigenisation, her insistence on the group's capacity to make the foreign familiar is functional. For Roos, indigenisation in this case is achieved not by drawing on South African musical styles and staging practices, but rather by invoking collective ideals of compassion and affirmation. ${ }^{36}$ In such a reading, however, the universal and the South African map onto each other rather uncomfortably. The 'Italian tradition' resides for Roos, it seems, in 'music-making, self-confirmation and shared humanity' - values that also happen to be characteristic of South African social life. Consequently, the physical aspects of staging, mise-enscène and performance make way for the abstract experience of singing together. This loses sight of a very real conundrum: what it could possibly mean for a group of coloured artists, singing and dancing at the southern tip of the African continent, to lay claim to a tradition of which they had little more than a vague idea. In short, while Roos reads the group's performances as instances of music-making that transcended apartheid South Africa's structural divisions by invoking a set of humanistic ideals, I want to argue that the realisation of the operas onstage in fact normalised the social inequalities of the time. In my reading, the idealised notion of an Italian operatic tradition functions not as a neutral aesthetic attribute, but as a historically and geographically situated construct, both racialised and classed.

\footnotetext{
35 Roos, 'Indigenisation and History', 128-9.

36 The PhD dissertation in which Roos first reconstructed the Eoan Group's history is entitled 'Opera Production in the Western Cape: Strategies in Search of Indigenization'.
} 


\section{Excess and grandeur: constructing class}

The Eoan Group's claim to an Italian tradition represented the first, crucial step in setting up a direct link between their productions and those in Europe. This link was further promoted by the material aspects of the group's productions. The stagings were more than physical settings for the singers: they functioned as symbolically charged sites of interaction and association between the players, their public and the distinct worlds they occupied.

Returning to the props list for the opening act of Eoan's 1956 Traviata, the first impression is of overload. Not satisfied merely with suggesting a realistic dining experience, for which half a dozen place settings would have been sufficient, the production's designers insisted on a full set of crockery and cutlery for each of the forty-eight singers on stage. Carefully counted out, these items suggest that the Eoan artists, rather than performing the simulacrum of a dinner party, were gathered on the City Hall stage to partake in an actual feast. Yet, it is doubtful that the entire cast would have sat down to a meal on stage, or, indeed, sat down at all, thus making it unlikely that those thirty chairs and four dozen serviettes would have played more than a visually suggestive role. Taking into account Andrew Sofer's definition of props as 'discrete, material, inanimate object[s] that [are] visibly manipulated by an actor in the course of performance', this multitude of onstage paraphernalia could not even qualify as props, for very few of them would have been 'visibly manipulated ... in the course of performance' ${ }^{37}$ Instead, they would have been little more than what Sofer calls 'onstage items'.

This pushes theatrical realism to its opposite extreme, tipping the naturalist scale towards flamboyance and excess. If, however, we exchange Sofer's performatively anchored approach for a materialist paradigm, Eoan's seemingly superfluous objects begin to carry greater weight than as the merely amateurish evocation of a distant theatrical convention. Sofer himself acknowledges that 'no recognisable object arrives on stage innocent'; rather, they bring

\footnotetext{
${ }^{37}$ Andrew Sofer, The Stage Life of Props (Ann Arbor, 2003), 11.
} 
'historical, cultural, and ideological baggage on stage with them'. ${ }^{38}$ Each item, in other words, represents a broader network of values. In apartheid South Africa, these were intimately connected with the realities of race and class. The elaborate luxury depicted onstage was, to a large extent, foreign to the Eoan singers themselves. Classified coloured by the apartheid government, they lived under a regime that exiled them to the literal and figurative back streets of poverty and proletarianism. ${ }^{39}$ The sumptuous dining, luscious settings and glittering finery should thus have been known to them only through depictions in the media of a world of privilege from which they were excluded by their racial status. From a position of racial, cultural and economic disenfranchisement, Eoan's staging summoned a larger framework of symbolic economies in which luxury signalled whiteness.

Sofer argues that 'arbitrary objects', those excessive articles known as 'onstage items', serve to disrupt the bond between the world created on stage and the context within which the theatrical event operates:

Surreal or arbitrary objects have neither use-function nor construable plot function; they are just there, pointing to themselves rather than to an external referent. Found only on the stage (or in a museum exhibition), arbitrary objects sever the link between stageworld and real world. Because of this, they are semidecorative and often divorced from narrative altogether. ${ }^{40}$

For Sofer, non-functional objects - those that are not props - dissolve the connection between stage and life because they serve no real-life purpose. 'Pointing to themselves', existing just for

\footnotetext{
${ }^{38}$ Sofer, The Stage Life of Props, 17, 11.

${ }^{30}$ See Zimitri Erasmus, ed., Coloured by History, Shaped by Place: New Perspectives on Coloured Identities in Cape Town (Cape Town, 2001); Mohamed Adhikari, Not White Enough, Not Black. Enough: Racial Identity in the South African Coloured Community (Athens, OH., 2005); and Richard van der Ross, In Our Own Skins: A Political History of the Coloured People (Johannesburg, 2015) on socio-political constructions and experiences of colouredness under apartheid.

${ }^{40}$ Sofer, The Stage Life of Props, 24.
} 
the sake of being there, they emphasise both their own artifice and the artifice of their staged environment. In the case of the Eoan Traviata, however, the opposite seems to be true. The selfreferentiality of the staging served to create a link between stage world and real world, albeit not a world that was real for the Eoan members. Their stage experience arguably did not constitute a sense of reality for the performers: it instead propelled them into a world normally denied them.

The grandeur evoked on stage clearly referenced a lifestyle reserved for the affluent classes of white South Africa. That these individuals were perceived to be the main supporters of Eoan's operatic endeavours was reflected explicitly in the advertising on the group's playbills. Promoting a variety of luxury goods, from fine silverware to liquor, ${ }^{41}$ these insets not only targeted a public of privilege and sophisticated taste, but also projected these qualities onto the audience. As Mark Gauntlett argues, theatre programme advertisements 'work to confirm the reader's membership of a group whose social standing and cultural disposition place him or her above the everyday and the common'. ${ }^{42}$ In other words, people who attend theatre productions and read their programmes are distinguished, and the advertisements they encounter are designed to emphasise their status. The advertisements extended beyond merely peddling goods, and served to create a public - one in possession of money, sophistication and class.

A figurehead for this public was the fur-clad woman gracing the full-page Morris Oxford advertisement in the 1956 Arts Festival Programme (Figure 4). Coiffed and bejewelled, she smiles on the arm of a man in evening dress. They have 'arrived', the advertisement proclaims presumably at the opera, judging by the words 'A fine performance...' arranged along the top of the page - but also in life:

41 'Wm. Spilhaus \& Co. Ltd.', 'Programme, Opera and Ballet Season, March 1958' (Eoan Group Archive, Copies from Mrs Ruth Fourie); 'Good Old Chateau, the Aristocrat of Brandies', 'Programme, 1956 Arts Festival'.

${ }^{42}$ Mark Gauntlett, 'Theatre-going, Theatre Programmes, Tourism', Australasian Drama Studies 22 (1993), 113-27, at 115 . 
You have arrived ... relaxed, and at ease; proud of the envious glances your Morris

Oxford has attracted; secure in the knowledge that its dignified lines and its spacious and elegantly finished interior, ensure you an extra confidence on these occasions ... ${ }^{43}$

What was to be experienced here was not only the authentic production of Italian opera, but also the authentic reconstruction of the world of privilege and grandeur associated with opera and whiteness. The playbills espoused a world of affluence and envy that was both real and imaginary: real for the white elite that frequented the Eoan Group's operas, and imaginary for the singers who interacted with this world on stage. Hence, the staging served both to alienate and to unite: the elaborate detail of the productions - simultaneously conjuring realism and fantasy - supported the inhabiting of a white world by the coloured bodies of the Eoan singers.

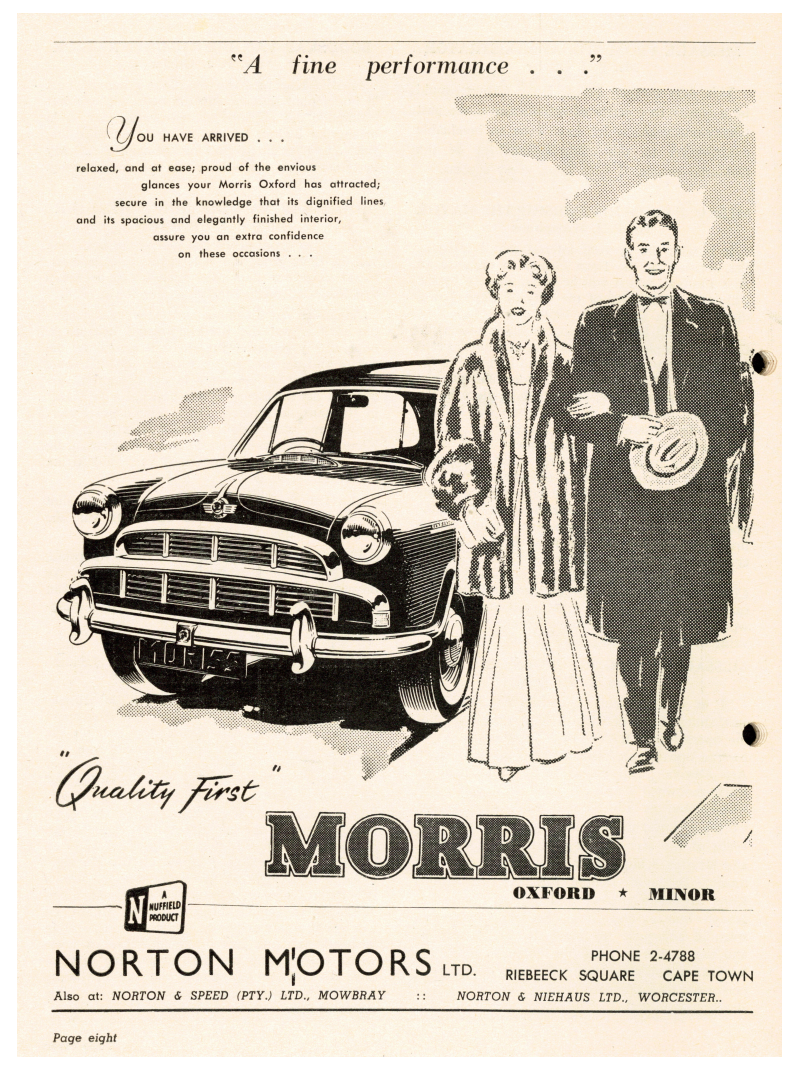

Fig. 4: Advertisement for Morris Oxford, in Programme, 1956 Arts Festival, 29:200. Reproduced with Permission.

43 'Morris Oxford', 'Programme, 1956 Arts Festival'. 


\section{'Really just dark Europeans': claiming whiteness}

At this point, it is worth clarifying the direct mapping of 'Europe' onto 'whiteness'. In the context of apartheid South Africa, 'European' and 'white' cannot easily be separated. Even in the racial nomenclature of the time, the two concepts were conflated, with whites often referred to in official documents as 'Europeans'. ${ }^{44}$ Additionally, opera in pre-democratic South Africa was regarded as 'almost the exclusively sole preserve of the White South African community', ${ }^{45}$ thus further emphasising the link between whiteness and European culture that is so crucial to this argument. The white people who recognised an Italian tradition in the Eoan Traviata drew not only on the authority of their social class, but also on a racially determined European heritage that ostensibly granted them familiarity with the operatic form and power to endorse its emulation. Represented by dazzling costumes, lavish scenery and extravagant dining, the Eoan Group's fantastical version of the Italian operatic tradition happened to resemble a similarly extraordinary image of affluent white, South African life. ${ }^{46}$

While the material realism enacted on the Eoan stage arguably signalled the singers' entry into a privileged white world, critics regarded the lavish spectacle of the group's performances as indicative of a close kinship between coloured people and Italians. That the Eoan artists were so seemingly at home in this realm - inhabiting the glittering stage, and the musical tradition of which it was part, with ease - destabilised the assumption of white proprietorship over the trappings of both European culture and privileged life, and compelled their public to search for an explanation that could safeguard its own racial exclusivity while upholding its capacity to recognise tradition when confronted with it. The result was a reception discourse that purchased

\footnotetext{
${ }^{44}$ See Pierre L. Van Den Berghe, South Africa: A Study in Conflict (Berkeley, 1965), 38, on the conflation of European culture with whiteness in early apartheid South Africa.

${ }^{45}$ Julius Eichbaum and Henning Viljoen, 'Opera in South Africa-Where are We Going Wrong?', Scenaria 78: July (1987), 23-4 (Eoan Group Archive 62: no folder).

${ }^{46}$ See Njabulo Ndebele, 'The Rediscovery of the Ordinary: Some New Writings in South Africa', in Rediscovery of the Ordinary: Essays on South African Literature and Culture (Scottsville, 2006 [1991]), 41-59, on the exhibitionism of white privilege under apartheid.
} 
for Eoan's singers a status resembling that of 'honorary Italians'. An appreciative audience member reflected on this in a letter to the Sunday Express:

This operatic achievement affirms a hitherto unsuspected affinity between Table Bay and the Bay of Naples - the shores of both, it seems, resound to natural, instinctive song. Even the olive tint of those Cape complexions seemed nothing more than a Neapolitan floridness. $^{47}$

Proceeding from the 'operatic achievement' of the Eoan Group to a reassessment of their skin colour, the critic here suggests that the group's operatic activities not only summon up an Italian musical tradition, but that they also signal a hereditary relation between coloureds and Italians. As reductive as it seems, this was not an entirely unusual view. Indeed, Joseph Manca himself commented as follows on coloured people's 'natural flair for music, rhythm and normal harmonies':

They [coloureds] are really dark Europeans. Their way of life is Western. Their religion is Christian. They live like us. They think like us. ${ }^{48}$

Manca goes beyond suggesting that coloured people were not really as distinct from whites as apartheid ideology claimed, and proposes that his coloured singers were genetically predisposed toward Italian opera. Italians, located in the south of Europe, were themselves 'dark Europeans' - their 'Neapolitan floridness' hardly distinct from 'the olive tint of those Cape complexions'. It was therefore only to be expected that the 'dark Europeans' of southern Europe and the 'dark Europeans' of southern Africa would share an operatic affinity. Here, a conflation of two groups

47 'Operas Worthy of Italy', Sunday Express, 21 August 1960 (Eoan Group Archive 30:208).

48 'Servants, Teachers in Eoan Group Cast', Daily News, 12 August 1960 (Eoan Group Archive 30:208). 
of 'others' (Italians as Europe's other, and coloureds as the other of whites), located in two versions of 'the south', is naturalised. Both Italians and coloureds displayed a 'natural flair for music, rhythm and normal harmonies', which found expression in 'natural, instinctive song'. Eoan's decision to perform Italian opera was hence racially and culturally appropriate, in apartheid terms, at least.

A similar sentiment surfaced in critic Lewis Sowden's review of La traviata:

The Eoan Group comprise Coloured people presumably developing along their own lines. And what do they develop? They show an extraordinary interest and capacity in Italian opera, in a sense the most sophisticated of the arts, thus staking their claim to belong to us, our culture and our future - as assuredly they do. ${ }^{49}$

Rather than concluding that Italian opera was evidently not the preserve of whiteness, Sowden determined that the Eoan Group's predilection for 'white art' demonstrated that coloured people belonged to the white race. Attempts such as these to express admiration for the achievements of the singers served instead to signify a condescending hierarchy of racial accomplishment, and to reinforce the belief that anything worthwhile could only be produced by those who shared or had access to an inheritance of European sophistication. In apartheid South Africa opera, as a European art form, remained as closely intertwined with 'white culture' as it was evocative of an Italian heritage. The Eoan Group's dedication to the faithful enactment of this culture unavoidably implicated them in a tacit surrender to white cultural hegemony.

The operatic race-determinism identified here strongly evokes Kristen M. Turner's observation, in relation to African-American opera at the turn of the twentieth century, that white critics seemed to respond to 'a "whiting" effect that the act of singing European works

\footnotetext{
${ }^{49}$ Lewis Sowden, 'A “Traviata” of Irony and Enjoyment', undated, source unknown (Eoan Group Archive 60:494a).
} 
had on their perceptions of the performers' ${ }^{50}$ As Turner argues, African-American artists' participation in Western musical forms served to make their race seem less conspicuous, rendering their blackness 'inaudible, and thus nonsignifying. ${ }^{51}$ Likewise, the Eoan Group operas negated participants' racial status. What is unique in Eoan's case, however, is the extent to which the material aspects of their performances contributed to this deracialisation. The productions' mise-en-scène firmly situated the group's coloured singers within an authentically European cultural heritage, and thereby purchased for the artists a racial standing they were denied by law.

Moreover, it reached beyond the localised specificity of South African whiteness, to claim for the Eoan Group an international inheritance of European artistry.

\section{Reaching for Europe}

That opera represented for the Eoan Group an aesthetic pinnacle extending beyond the parochial realities of South African cultural life was clear from the discourse surrounding their first Traviata. The opera's production programme described the venture as '[coloured people's] first international milestone in their march of endeavour for both social and educational upliftment [sic], ${ }^{52}$ thereby confirming the group's desire to be understood as partaking not in a local, but a global artistic discourse. Manca's solicitation of overseas publicity for La traviata further confirms his international ambitions for the group: writing to the British magazine Opera and the opera's publishers G. Ricordi \& Co., ${ }^{53}$ he sought to frame the production as an event of worldwide significance: 'Great stress is being laid on the importance of this particular production', he wrote to Ricordi, 'due to the fact that World Music History is being made in South Africa, ${ }^{54}$ In their response, which was printed in the 1956 Festival Programme, Ricordi

\footnotetext{
${ }^{50}$ Kristen M. Turner, 'Class, Race, and Uplift in the Opera House: Theodore Drury and his Company Cross the Color Line', Journal of Musicological Research 34 (2015), 320-51, at 347.

51 Christina L. Ruotolo (2013), cited in Turner, 'Class, Race, and Uplift', 347.

52 'Programme, 1956 Arts Festival'.

53 Correspondence, Manca to Harold Rosenthal (Opera), 2 April 1956 (Eoan Group Archive, 29:200); Manca to Miss Hasker of G. Ricordi, 18 November 1955.

54 Correspondence, Manca to Miss Hasker of G. Ricordi.
} 
embraced the internationalist rhetoric of Manca's letter, and expanded on it with observations on the significance of Eoan's project:

Message from G. Ricordi \& Co. (London), Publishers of 'La traviata': It is with particular pleasure that the music Publishing House of Ricordi salutes the choice of the opera 'La traviata' by Giuseppe Verdi for the opening performance of the Eoan Group Arts Festival. This being the first time that the world-renowned 'La traviata' has been performed by an all-Coloured cast, such praiseworthy and notable departure opens up stimulating vistas of the ever-widening influence of the arts, and stresses again the universal appeal of great music. ${ }^{55}$

Ricordi's acknowledgement of the 'ever-widening influence of the arts' signalled the international expansion of the performance and audience network of Verdi's operas (of undoubted value to the composer's publishers). Additionally, however, it hinted at a musical civilising mission responsible for 'open[ing] up stimulating vistas' to the coloured musicians who embraced it. The Eoan Group's ‘praiseworthy and notable departure' in performing Italian opera not only showed that Verdi's music had 'universal appeal', but also confirmed that the artists performing it had entered the cultural universe that could value this music, without needing to alter it to suit their tastes or to reflect local musical practices.

If Ricordi's statement referred only obliquely to the continued spread of the civilising benefits associated with Western art music, Manca embraced such ideology openly. In a lengthy introduction to the 1956 season, he outlined the enlightening properties of Italian opera:

The Eoan Group's presentation of the Italian Opera 'La Traviata' is not only an epochmaking event of great import, but also represents the boldest and most thought-provoking

55 'Programme, 1956 Arts Festival'. 
experiment in the musical and cultural history of both the City of Cape Town and South Africa as a whole. ... The presentation of 'La 'Traviata' is the dawn of a 'New Era' for the Coloured People in their endless striving and unquenchable thirst for the higher things of life - an era of knowledge and culture hitherto unknown. This introduction into the magical world of 'Opera', apart from its entertainment value which is incidental to the real purpose of this venture, is the Coloured People's first intimate contact with one of the highest forms of musical art - an unforgettable baptism at whose font new horizons appear on the educational landscape of the Coloured People's activities, while new vistas of beauty are painted on the artistic canvas of their cultural progress. ${ }^{56}$

Initiating for coloureds 'an era of knowledge and culture hitherto unknown', the production of La traviata, Manca proclaimed, signalled a decisive step towards European civilisation. The allcoloured presentation of an Italian opera confirmed that coloureds were capable of participating in 'white culture', and that they were firmly on their way towards reaching Western levels of development. Manca's stipulation that the 'entertainment value' of the group's first operatic endeavour was 'incidental to the real purpose of this venture' highlights, yet again, the fact that the vision they mounted at City Hall was not simply an instance of spectacle for its own sake. First savouring 'the higher things of life' on stage, the Eoan singers' 'cultural progress' would ensure that they'd soon be enjoying these luxuries in real life too.

The astonishing paternalism of Manca's views was not unusual. As already shown, white South Africa reacted with condescending wonder to the Eoan Group's operatic success. Emol, whose comment on the historical significance of the La traviata costumes appears above, exclaimed in the same review that he 'would not have believed it if someone had told [him] in

56 'The Eoan Group Arts Festival: Introductory Remarks by Joseph Manca'. 
great detail beforehand what [he] would see and hear on Saturday night [10 March 1956]. ${ }^{57}$ This was Rota's miracle indeed. Other newspapers similarly promulgated the group's success, with such headlines as 'Distinguished Audience Acclaimed La traviata ${ }^{58}$ taking care to highlight not only the group's musical triumph, but also the white public's role in declaring it as such.

Within the politically charged atmosphere of apartheid South Africa, the 'whitemindedness' of the Eoan Group's operatic offering, combined with the patronising nature of the reviews printed in the white media, was bound to generate controversy. While a detailed discussion of the political reception of Eoan's first La traviata is beyond the scope of this article, a few words on the fallout from this event and its stylisation in the white media will be useful. Shortly after the premiere, the group received a letter from the Coloured People's Organisation (CPO), an anti-apartheid movement based in the Western Cape. CPO's administration, the letter states, had become aware of the fact that the Eoan Group had received funding from the apartheid government's controversial Department for Coloured Affairs, and that the group had subsequently agreed to put on a 'whites-only' performance for dignitaries, cabinet ministers and other 'prominent racialists'. ${ }^{59}$ In a stern rebuke, the letter determines that 'the whole idea reminds one of the slave period when the farmers hired Coloureds to perform for them, their masters', and assured the group that 'all advanced and progressive people bowed their heads in shame when you performed follow[ing] the footsteps of your slave forefathers'. Finally, it expresses 'hope that, when the same situation arises in the future, you will consider it in the light of this letter and be prepared to uphold the dignity of people struggling for emancipation' by refusing to perform. Despite its objections, the CPO nonetheless recognised the apparent value of the Eoan Group's operatic endeavour, opening its communiqué with a word of acknowledgement:

\footnotetext{
${ }^{57}$ As iemand my haarfyn sou vertel het wat ek. Saterdagaand sou sien en hoor, sou ek hom nie geglo het nie. Emol, 'Kaapse Kleurlinge Voer Italiaanse Opera met Groot Welslae Uit, Die Burger, 12 March 1956.

58 The Cape Argus, 21 March 1956 (Eoan Group Archive, Ruth Fourie Newspaper Cuttings).

${ }^{59}$ Letter from South African Coloured People's Organisation, signed by Chairman Alex La Guma and Secretary R. September, undated (Eoan Group Archive 29:200).
} 
Allow us to congratulate you on your magnificent performance of "La Traviata". You have shown that, given the opportunities, Coloured people can excel in the realms of culture on par with all other people.... Since its birth the Group has rendered invaluable service to the cultural well-being and advancement of our community and country ...

Identifying in Eoan's Traviata a realisation of coloured people's cultural potential and a contribution to the 'well-being and advancement' of their race, the CPO seems to subscribe to the same aspirational model articulated by the Eoan Group. Their disapproval was not provoked by the singers' participation in so-called 'white culture', but by their financial affiliation with the apartheid government and their acquiescence to its segregationist policies. The objection, in other words, was practical, rather than ideological.

A far more incendiary denunciation, explicitly preoccupied with the group's propagation of white cultural values, was published anonymously in the first edition of The Citizen, a fortnightly newspaper produced between March 1956 and May 1958 by a Cape Town-based Marxist resistance group called The Heatherly Civic Association. The article, entitled 'The La Traviata Affair' and published on 31 March 1956, rails at the condescending attitudes expressed by the press towards the Eoan Group, before launching an attack on the group itself, likening its activities to 'Coon Opera' and identifying in them no less than a cultural inferiority complex:

We do not share the amazement the columns of the daily press oozed out over the recent production of Italian opera by a so called 'All Coloured Cast'. We are not surprised that human beings can sing, dance, and act.

How ever the undoubted enthusiasm of both the performance and the majority of the audience for 'La Traviata' is an [index] of the cultural starvation and hunger of the majority of the people, cut off as they are by apartheid and poverty from the best in art and culture. 
It is precisely this cultural starvation of the mass of the people that has tricked them into accepting Eoan's La Traviata as a step towards their cultural aspirations. In the same way a man driven by a burning thirst will drink at a sewer for the sake of life itself. ... Eoan's La Traviata, therefore, whatever degree of technical skill achieved, whatever amount of talent displayed or standard of production reached, can only be characterised as 'Coon Opera'. The elegance and high artistic form merely substitutes for the capering and cavorting of the New Year revellers. The Essence of coonery is still there for all to see - the voluntary self abasement and degradation of an oppressed people for the pleasure of those who oppress, despise and insult them. The activities of racialists who defraud the people into believing that their aspirations for a higher cultural life can be achieved on the sordid basis of coonery, are revolting, and worthy only of the strongest condemnation. They have gone a long way in turning the aspirations of human beings for a richer life into an acceptance of a degraded position bereft of dignity and self respect $[\mathrm{sic}] .^{60}$

'Coonery' here refers to the traditional New Year Celebrations associated with Cape coloureds, in which male marching bands clad in colourful costumes and made up in whiteface parade through Cape Town singing and playing a variety of popular and traditional songs. As is evident from this citation, the 'Coon Carnival' (recently renamed in official discourse as the Cape Town Minstrel Festival, or Kaapse Klopse), with its origins in Cape Town's slave history, became an enormously contentious cultural practice during apartheid. Denis-Constant Martin argues that the coloured intelligentsia, in concert with the anti-apartheid movement, viewed the Klopse as 'a degrading exercise where participants were seen as impersonating clowns and making spectacles

60 'The La Traviata Affair’, 31 March 1956 (Eoan Group Archive 29:200). 
of themselves for the pleasure and amusement of their white masters', ${ }^{61}$ thereby reinforcing racist stereotypes relating to coloureds' frivolity, drunkenness and lack of sophistication. ${ }^{62}$ By characterising Eoan's La traviata as 'Coon Opera', the Citizen proposes that the group's members had internalised the same discourse of coloured subordination espoused by their working-class Klopse counterparts. The extravagant fashions of the La traviata stage were but a more glamorous version of the colourful suits worn by the 'New Year revellers'; the stage make-up donned by the singers an officially sanctioned variation on the Coons' whiteface. ${ }^{63}$

The 'La Traviata Affair' article made its way into the Eoan Group archive as a typed copy, reproduced on light blue letter-writing paper. In the left margin, a note in what resembles Manca's handwriting is appended: 'This I typed to let you know [illegible] though I realise not worth worrying about'. ${ }^{64}$ Indeed, the group did not seem to worry, for many years at least, about the objections expressed by both the CPO and The Citizen. Only in the 1970s, when Eoan's politically compromised past caught up with it, did the group come to appreciate the gravity of the cautionary note sounded in these initial demurrals. ${ }^{65}$ During the first, heady years of operatic success, Manca and his band of artists did not concern themselves with political protestations, for they had found a more meaningful way to inhabit their abject, coloured reality.

\section{Conclusion}

Bound inescapably by the material confines of apartheid's racial classifications, the Eoan Group's 1956 La traviata created an alternative, 'white' reality on stage. It prompted a symbolic

\footnotetext{
${ }^{61}$ Denis-Constant Martin, 'What's in the Name "Coloured”?', Social Identities 4 (1998), 523-40, at 530. See Martin's Coon Carnival: New Year in Cape Town: Past to Present (Cape Town, 1999) for more on this topic. ${ }^{62}$ For an in-depth discussion of coloured identity, its stereotypical treatment in apartheid South Africa and the impact this had on the activities and aspirations of the Eoan Group, see Pistorius, 'Eoan, Assimilation, and the Charge of "Coloured Culture", SAMUS: South African Music Studies 36/37 (2017), $389-415$.

${ }^{63}$ For more detailed discussions of this article, and of the group's political reception in general, see Pistorius, 'Coloured Opera as Subversive Forgetting', Social Dynamics: A Journal of African Studies 43 (2017), $230-42$.

64 'The La Traviata Affair', 31 March 1956 (Eoan Group Archive 29:200).

${ }^{65}$ On the politically prompted demise of the Eoan Group's music section, see Eoan History Project, Eoan: Our Story (Johannesburg, 2013); Roos, 'Remembering to Forget'; and Pistorius, 'Eoan, Assimilation'.
} 
displacement of colouredness, while reinscribing whiteness as the site of enfranchisement. Thus, the 'Italian tradition' emulated in the opera's staging both influenced and reflected the political implications of the production. In its design and direction, La traviata sought to construct a direct hereditary link with an imagined European operatic tradition, thereby to situate the coloured members of the group within idealised whiteness. Following Vlado Kotnik, Eoan's La traviata was not merely about 'performing a musical work on stage', but about performing 'a highly contested social arena'.66

In Eoan's Traviata, both on stage and off, in programme advertisements and audience reception, the white world was constructed as one of glamour, magnificence, luxury and leisure. But the excess and ostentation suggested in the opera's production inventories are simultaneously tempered by the very quotidian nature of these lists. Borrowed furniture; artificial flowers; empty champagne bottles: these items somehow undermine the magic of the stage, turning this enchanted domain into lists of everyday objects. While the Eoan Group's props supposedly conjured a world of which the singers could not otherwise be part - a material abundance they could not possess - the sheer excess of everyday goods with which they populated their stages simultaneously destabilised their operatic escapism, and situated them within the inglorious reality of operatic labour, of making something out of nothing. Approaching whiteness, they became the others of themselves. Yet, they remained beholden to the ordinary stuff from which they sought to build their white fantasies: they could never quite enter the idealised world of luxury they emulated. Instead, they remained caught between empowered whiteness, and the mundane actuality of disenfranchised coloured life. These stagings - simultaneously extraordinary and commonplace - shed light on the enormous ideological weight carried by convention.

${ }^{66}$ Vlado Kotnik, 'The Adaptability of Opera: When Different Social Agents Come to Common Ground', International Review of the Aesthetics and Sociology of Music 44 (2013), 303-42, at 303. 
Approaching 'the Italian tradition' from a materialist, rather than a text-based perspective, this article shows that operatic convention itself fulfils a profound ideological purpose. The 'safe', 'predictable' and 'basically naturalistic settings ${ }^{67}$ of the Eoan Group operas garnered meaning through synthesis with the historical and geographical specificities of apartheid South Africa. Operatic commonplaces - often neglected in favour of 'the unusual or the curious, the exceptional or the difficult' should not be dismissed out of hand. ${ }^{68}$ As the Eoan operas show, tradition is itself never neutral. Instead, it serves to distil the deeply politicised aspirations and impossibilities of cultural life. Truth is always political. Though what they presented onstage was arguably no more than a faithful enactment of the scenarios outlined in the score, the Eoan Group's audiences deemed them to represent an Italianate authenticity, both in culture and in race. Thus, the 'Italian tradition' was more than an aesthetic model; it became the banner under which a band of coloured singers inhabited whiteness.

67 Gossett, Divas and Scholars, 452.

68 Dotto, 'On “'Traditional” Performance', 152. 